Monetary Co-operation with France was signed. The five original members, Cameroon, Central African Republic, Chad, Republic of the Congo and Gabon, were joined by Equatorial Guinea in 1985. Under its Convention and statutes, the BEAC is declared a 'Multinational African institution in the management and control of which France participates in return for the guarantee she provides for its currency'.

Official language: French.

Headquarters: Avenue Monseigneur Vogt, Yaoundé, Cameroon.

Website: http://www.beac.int (French only)

Governor: Philibert Andzembe (Gabon).

Publications. Etudes et Statistiques (monthly bulletins); Annual Report; Directory of Banks and Financial Establishments of BEAC Monetary Area (annual); Bulletin du Marché Monétaire (monthly bulletins); Annual Report of the Banking Commission.

\section{Central Bank of West African States (BCEAO)}

Established in 1962, the Central Bank of West African States (Banque Centrale des Etats de l'Afrique de l'Ouest) is the common central bank of the eight member states which form the West African Monetary Union (WAMU). It has the sole right of currency issue throughout the Union territory and is responsible for the pooling of the Union's foreign exchange reserve; the management of the monetary policy of the member states; the keeping of the accounts of the member states treasury; and the definition of the banking law applicable to banks and financial establishments.

Members. Benin, Burkina Faso, Côte d'Ivoire, Guinea-Bissau, Mali, Niger, Senegal, Togo.

Official language: French.

Headquarters: Avenue Abdoulaye Fadiga, Dakar, Senegal.

Website: http://www.bceao.int

Governor: Philippe-Henri Dacoury-Tabley (Côte d'Ivoire).

Publications. Rapport annuel (annual); Annuaire des Banques (annual); Bilan des Banques U.M.O.A. (annual); Notes d'information et statistiques (monthly bulletin).

\section{Common Market for Eastern and Southern Africa (COMESA)}

COMESA is an African economic grouping of 20 member states who are committed to the creation of a Common Market for Eastern and Southern Africa. It was established in 1994 as a building block for the African Economic Community and replaced the Preferential Trade Area for Eastern and Southern Africa, which had been in existence since 1981 .

Members. Angola, Burundi, Comoros, Democratic Republic of the Congo, Djibouti, Egypt, Eritrea, Ethiopia, Kenya, Libya, Madagascar, Malawii, Mauritius, Rwanda, Seychelles, Sudan, Swaziland, Uganda, Zambia and Zimbabwe.
Objectives. To facilitate the removal of the structural and institutional weaknesses of member states so that they are able to attain collective and sustainable development.

Activities. COMESA's Free Trade Area (FTA) was launched on 31 Oct. 2000 at a Summit of Heads of States and Government in Lusaka, Zambia. The FTA participating states have zero tariff on goods and services produced in these countries.

In addition to creating the policy environment for freeing trade, COMESA has also created specialized institutions like the Eastern and Southern African Trade and Development Bank (PTA Bank), the PTA Reinsurance Company (ZEP-RE), the Clearing House and the COMESA Court of Justice, to provide the required financial infrastructure and service support. COMESA has also promoted a political risk guarantee scheme, the Africa Trade Insurance Agency (ATI), a Leather and Leather Products Institute (LLPI), as well as a cross-border insurance scheme, the COMESA Yellow Card.

Official languages: English, French, Portuguese. Headquarters: COMESA Secretariat, COMESA Centre, Ben Bella Road, PO Box 30051, 10101 Lusaka, Zambia. Website: http://www.comesa.int Secretary General: Erastus Mwencha (Kenya).

\section{East African Community (EAC)}

The East African Community (EAC) was formally established on 30 Nov. 1999 with the signing in Arusha, Tanzania of the Treaty for the Establishment of the East African Community. The Treaty envisages the establishment of a Customs Union, as the entry point of the Community, a Common Market, subsequently a Monetary Union and ultimately a Political Federation of the East African States. In Nov. 2003 the EAC partner states signed a Protocol on the Establishment of the East African Customs Union, which came into force on 1 Jan. 2005.

Members. Burundi, Kenya, Rwanda, Tanzania, Uganda.

Headquarters: PO Box 1096, Arusha, Tanzania. Website: http://www.eac.int

Secretary General: Juma Mwapachu (Tanzania).

\section{East African Development Bank (EADB)}

Established originally under the Treaty for East African Cooperation in 1967 with Kenya, Tanzania and Uganda as signatories, a new Charter for the Bank (with the same signatories) came into force in 1980. Under the original Treaty the Bank was confined to the provision of financial and technical assistance for the promotion of industrial development in member states but with the new Charter its remit was broadened to include involvement in agriculture, forestry, tourism, transport and the development of infrastructure, with preference for projects which promote regional co-operation.

Official language: English.

Headquarters: 4 Nile Avenue, Kampala, Uganda.

Website: http://www.eadb.org

Chairman of the Board: Ezra Suruma (Uganda). 